DOI 10.18551/rjoas.2021-06.14

\title{
EFFECT OF JATROPHA CURCAS (LINN) STEM-BARK EXTRACT ON CONTROL OF CATTLE TICKS
}

\author{
Okeke-Agulu K.I. ${ }^{1 *}$, Onuwa G.C. ${ }^{1}$, Adeniyi O.O. ${ }^{2}$, Mailumo S.S. ${ }^{1}$, \\ Bayo D.I. ${ }^{2}$, Kyaharle B.S. ${ }^{3}$ \\ ${ }^{1}$ Department of Agricultural Extension and Management, Federal College of Forestry, \\ Jos, Nigeria \\ ${ }^{2}$ Montane Forest Research Station, Jos, Nigeria \\ ${ }^{3}$ Department of Pest Management Technology, Federal College of Forestry, Jos, Nigeria \\ *E-mail: okekeaguluki@gmail.com
}

\begin{abstract}
The use of Jatropha curcas leaf extracts in the control of ticks that infest cattle and other large farm animals was studied in the bid to developing environmentally safer acaricides and their attendant deleterious effects on other organisms. Stem-bark of Jathropha curcas was collected from the premises of Federal College of Forestry Jos, air dried, pulverised, sieved and the powder was dissolved in distilled water for 24 hours and then filtered. The filtered solution was used to test for presence phytochemicals. Completely Randomized Design was used to distribute Seven hundred and twenty (720) ticks in petri dishes with tissue papers soaked with the extract; of 4 treatments (length of time of stem-extract storage) and 3 replications. Result showed the presence of the following phytochemicals; glycosides, saponins, alkaloids and tannins in high quantities. Ticks treated with extract at zero hour of storage, resulted to $93 \%$ mortality, after 6 hours of storage $84 \%$ mortality, after 12 hours of storage, $66 \%$ mortality and after 18 hours of storage, $57 \%$ mortality. From the finding, as the length of storage increases, the rate of mortality of the ticks decreases. The analysis of variance showed that there are significant differences in mortality existing between the various treatments. Therefore, it is suggested that farmers may use fresh extracts in controlling ticks while further research is being carried out to increase the mortality rate. More research should also be carried out in the area of toxicity or possible side effect, if any on animals.
\end{abstract}

\section{KEY WORDS}

Jatropha curcas, ticks, acaricides, stem-bark extract, phytochemicals, mortality.

The traditional livestock management system in Nigeria has always been the practice of rearing cattle in grass lands and forests in search of food and water. This practice exposes them to infestation by the three tick genera known in Nigeria. These include, Ambyomma, Hyalomma and Rhipicephalus spp. (Dipeolu, 1975; Awogbade, 1979; Pullan, 1980; Bayer and Maina, 1984).

Farmers in the bid to control the ticks rely heavily on the use of chemicals known as acaricides for effective tick control (Lorusso et al., 2013). The need to have non-chemical methods and products with different mode of action in the control of ticks can never be over emphasised especially in the bid to solve the problem of ticks' resistance to synthetic acaricides (Graf et al., 2004). Regrettably, tick control with synthetic acaricides has been observed to leave deleterious residues, environmental pollution, and more importantly, they are very expensive (Ghosh et al., 2007). Gionetto and Chavez (2000) in their work noted that metabolites of plant origin reduce the persistence and accumulation of pesticides in the environment, since they are biodegradable and with no side effects.

Adenubi et al. (2016) had noted that Azadirachta indica, Gynandropsis gynandra, Lavendula augustifolia, Pelargonium roseum and Cymbopogon spp. had good acaricidal effects with $90-100 \%$ efficacy, comparable to those of currently used acaricides. However, their list did not include Jatropha curcas which is in great abundance in the study area.

Jatropha curcas Linn belongs to the family Euphorbiaceae and are used in ethno 
botanic medicine in Africa, Asia and Latin America (Burkill, 1994). The plant is native to North America but has been known to thrive well in Africa and Asia. It is easy to establish as it grows relatively quickly with high yields (Willis, 1967). It is one of the promising biodiesel plants. According to Okujagu et al. (2006), it is traditionally used to cure diseases like cancer, piles, snake bites, paralysis and dropsy. Sanis et al. (2011) had posited the efficacy of Jatropha Curcas extract in the control of ticks but their extract was from leaf. Not much research work has been done in the use of stem-bark extracts in the control of ticks. Hence, it becomes pertinent to assess the effect of stem-bark extracts in the control of Rhipicephalus (Boophilus) decoloratus.

\section{MATERIALS AND METHODS OF RESEARCH}

Jatropha stem-barks collected from Federal College of Forestry, Jos premises, were sun-dried, pulverised, sieved and the powder dissolved in water for 24 hours and then filtered following Damter (2000), at the rate $25 \mathrm{~g}$ to $250 \mathrm{mls}$ of water. The filtrate was then stored at $4^{\circ} \mathrm{C}$ in a refrigerator, until used.

Phytochemical Analysis. The plant extracts was assayed quantitatively to identify the phytochemicals it contains using the methods of Trease and Evans, (1989) and Sofowora, (1979). An extract of the fresh stem-bark of Jatropha curcas was prepared according to the method described by Sofowora (1979). $100 \mathrm{~g}$ of the fresh stem-bark was pounded in a clean mortar with pestle and macerated with $500 \mathrm{ml}$ of redistilled methylated spirit in a blender. This was suction filtered and the process repeated exhaustively with known volumes of redistilled methylated spirit. The filtrate was evaporated to dryness at $50^{\circ} \mathrm{C}$ and further dried to constant weight at the same temperature in a hot air oven. The yield of residue was $20.52 \pm 1.25 \mathrm{~g}$. This was used to test for the following plant constituents' resins, alkaloids, saponin, tannin, glycosides and flavonoid.

Test for resins. To $0.5 \mathrm{~g}$ of the stem bark extract was added $5 \mathrm{ml}$ of boiling ethanol. This was filtered through Whatmann No.I filter paper and the filtrate diluted with $4 \mathrm{ml}$ of $1 \%$ aqueous $\mathrm{Hcl}$.

Test for Alkaloids. $0.5 \mathrm{~g}$ of the extract was stirred with $5 \mathrm{ml}$ of $1 \%$ aqueous $\mathrm{Hcl}$ on a steam bath. This was filtered and $1 \mathrm{ml}$ of the filtrate treated with a few drops of dragendorffs reagent and a second $1 \mathrm{ml}$ formation treated similarly with wagner's reagent.

Test for Saponin. $0.5 \mathrm{~g}$ of the extract was shaken with water in a test tube. Frothing which persisted on warming was taken as preliminary evidence for the presence of saponin (Wall et al, 1952 and 1954).

In order to remove "false-positive" results, the blood haemolysis test was performed. $0.5 \mathrm{~g}$ of the extract was boiled with $50 \mathrm{ml}$ of phosphate buffer, $\mathrm{PH} 4$ and then allowed to cool and filtered. $5 \mathrm{ml}$ of the filtrate was passed for 13 hours through an asbestos disc which has been previously soaked with two or three drops of $1 \%$ cholesterol in ether and dried in the air. After filtration, the disc was washed with $0.5 \mathrm{ml}$ of distilled water, dried and boiled in $20 \mathrm{ml}$ of oxylol for 2 hours to decompose the complex formed between cholesterol and any saponin in the extract. The disc was then washed in ether, dried and placed on a $7 \%$ blood nutrient agar. There was Haemolysis of red blood cells around the disc after 6 hours.

Test for Tannin. $5 \mathrm{~g}$ of the extract was stirred with $10 \mathrm{ml}$ of distilled water. This was filtered and a few millilitres of $5 \%$ ferric chloride, added to the filtrate. A deep green coloration was seen. A second portion of the filtrate was treated with few millilitres of iodine solution. A faint bluish coloration was also seen.

Test for glycosides. $5 \mathrm{~g}$ of the extract was stirred with $10 \mathrm{ml}$ of boiling distilled water. This was filtered and $2 \mathrm{ml}$ of the filtrate hydrolysed with a few drops of conc. HCL and the solution rendered alkaline with a few drops of ammonia solution. 5 drops of this solution was added to $2 \mathrm{ml}$ of Benedict's qualitative reagent and boiled. A reddish brown precipitate appeared.

Test for Flavonoid. $0.5 \mathrm{~g}$ of the extract was dissolved in $2 \mathrm{ml}$ dilute $\mathrm{NaOH}$ solution. A few drops of conc. $\mathrm{H}_{2} \mathrm{SO}_{4}$ was then added. The presence of flavonoid is indicated if the solution becomes colourless (Trease and Evans, 1989). 
Collection of Ticks and Grouping. The ticks were collected from Kasuwan Shanu in Jos and were randomly distributed into twelve glass jars with sixty (60) ticks in each separate glass jar. A total number of 720 ticks were used and divided into four (4) treatments and three (3) replicates. Filter papers were soaked with the extract, allowed to partially dry before placing the ticks on them.

The first group (T0) was added the 10\% concentration of the extract, fresh without storage (at zero hour). To the second group (T1) was added the $10 \%$ concentration of the extract after 6 hours of storage in the refrigerator at $4^{\circ} \mathrm{C}$. To the $3^{\text {rd }}$ group (T2) was added $10 \%$ of the extract after 12 hours of storage. To the $4^{\text {th }}$ group (T3) was added $10 \%$ of the extract after 18 hours of storage. Completely Randomised Design was the experimental design used in the study. Analysis of variance (ANOVA) was used to check if the means of the treatments are significantly different from each other.

\section{RESULTS AND DISCUSION}

Jatropha curcas contain glycoside, Saponins, Alkaloids and Tannin all in high quantities while Resin and flavonoid are absent in the plant. This result agrees with the findings of Askira and Sodipo (2002). Test for resins indicates that there was no formation of a heavy resinous precipitate which indicates the absence of resins. Alkaloid was present; there were formation of precipitates as indicated by Trease and Evans, (1989). Test for saponin shows that frothing which persist on warming after shaking $0.5 \mathrm{~g}$ of the extract with water in a test tube was taken as preliminary evidence for the presence of saponin (wall et al., 1952 and 1954). Haemolysis of red blood cells around the disc after 6 hours was taken as further evidence of presence of saponin (Trease and Evans, 1989). Test for Tannin shows that, there was a deep green coloration which showed the presence of tannin. A faint bluish coloration after treating the filtrate with iodine solution confirmed the presence of tannin (Trease and Evans, 1989). Test for glycosides, showed a reddish brown precipitate which indicates the presence of glycosides (Trease and Evans, 1989). Test for flavonoid revealed that, it was absent, the solution was not colourless as put forward by Trease and Evans, (1989).

Tannins is used in styptic preparations which produces contractions of blood vessels; stopping bleeding having the quality of retaining haemorrhages when applied to the bleeding part (McGraw-Hill, En. 1977). Saponins have the property of Causing haemolysis of cells even at low dilution, tend to be deposited on the surface of cells with which they come in contact and are not absorbed by the normal epithelium of the alimentary canal (Arthur et al., 1941). Alkaloid represents the active principle of vegetable drugs. They are alkaline in reaction and richly combine with acid forming salts soluble in water. All contain nitrogen but some drugs may contain more than one alkaloid and the actions of these may be antagonistic (Russell et al., 1956).

Glycosides have a tendency to block the conduction of the electrical impulse that causes contraction as it passes from the atria to the ventricles of the heart (heart block). Cardiac glycoside also have a tendency to produce an abnormal cardiac rhythm by causing electrical impulses to be generated at points in the heart other than the normal pace maker region, the cells that rhythmically maintain the heartbeat (Encyclopaedia Britanica, 2005).

Table 2 - Showing different Treatments of Aqueous Extract of Jatropha curcas on Ticks

\begin{tabular}{llllll}
\hline & 1 & 2 & 3 & Total \% & Mean \\
\hline T0 & 60 & 56 & 52 & 16893 & 56 \\
T1 & 48 & 48 & 56 & 15284 & 51 \\
T2 & 36 & 44 & 40 & 12066 & 40 \\
T3 & 40 & 28 & 36 & 10457 & 35 \\
\hline Total & 184 & 176 & 184 & GT $=544$ & \\
\hline
\end{tabular}

Table 2 shows the effect of the plant Extract on ticks at different treatments (length of storage) ranging from zero hour, six hours, twelve hours and eighteen hours all at the same $(10 \%)$ level of concentration. 
From this result, it clearly indicate that when the treatment was applied at zero hour (fresh) it yielded up to (93\%) 42 rate of mortality. At six hours length of storage, the mortality rate drops to (84\%) 38. At twelve hours length of storage, the mortality rate obtained was $(66 \%) 30$ and $(57 \%) 26$ mortality at eighteen hours length of storage.

From this result, it shows that as the length of storage of the aqueous extract of the plant increases, the mortality rate decreases there is significant difference in the effect of different treatments of aqueous extract of the Jatropha curcas on ticks. The result obtained from fresh use of Jatropha curcas extract $(93 \%)$ is comparable to that obtained by Adenubi et al. (2016) from Azadirachta indica, Gynandropsis gynandra, Lavendula augustifolia, Pelargonium roseum and Cymbopogon spp., whose acaricidal effects is within $90-100 \%$ efficacy.

Possible mode of action of the Phytochemicals on the ticks. Based on table 2, arid the method of application used (which was applied on the White-man paper, allowed to partially dry before placing the ticks on it) shows that the possible mode of action of the plant may be through contact with extract or by inhalation. The plant as discussed in table 1 has the following photochemical properties, glycosides, saponins, alkaloids and tannin all in higher quantities. Like saponins for instance have the property of causing haemolysis of cell even at low dilution, tend to be deposited on the surface of cells with which they come in contact and are absorbed by the normal epithelium of the alimentary canal (Arthur et al 1962). Alkaloids, saponins, and tannins have been recorded to have retrogressive effect on micro-organisms (Block, 1985) Tannins are used in styptic preparations which produces contractions of the blood vessels, stopping bleeding, having the quality of retaining haemorrhages when applied to the bleeding part (McGraw-Hill, En. 1977) Alkaloids represent the active principles of vegetable drugs, They are alkaline 'in reaction and richly combine with acid forming salts soluble in water. All contain Nitrogen. Some drugs may contain more than one alkaloid and the actions of these may be antagonistic (Russell et al, 1956).

Worthy of Note is considering the pharmacological value of glycoside which causes cardiac (heart) problems and may be implicated.

It is equally important to note that the effect of the extracts upon treatments on the ticks were acute and rapid in action and not chronic. It is therefore, suggested that glycoside may be implicated, since the encyclopaedia Britanica (2005) reported that glycoside have a tendency to block the conduction of the electrical impulse that causes contraction as it passes from the atria to the ventricles of the heart (heart block). It also have a tendency to produce an abnormal cardiac rhythm by causing electrical impulses to be generated at point in the heart other than the normal pace maker region, the cells that rhythmically maintain the heartbeat. Saponin may also be implicated because of its ability to cause haemolysis of cells even at low dilution tends to be deposited on the surface of cells with which they come in contact and are not absorbed by the normal epithelium of the alimentary canal as reported by (Arthur et al., 1962) however, the effect of the plant extract, on the ticks may be as a result of a synergistic action Of all the phytochemicals.

\section{CONCLUSION}

From the results, the plant extract has great potentials in the killing of ticks when the extract is fresh. Mortality decreases as storage time increases. It is possible that its ability to achieve this may be as a result of a synergistic action of its phytochemicals or as a result of the action of individual phytochemicals which have been shown to have a retrogressive effect on organisms. The use of Jatropha curcas (Linn) stem bark extract when it is fresh is highly recommended in controlling ticks for best results. Further research should be carried out in the area of toxicity or possible side effects on animals.

\section{REFERENCES}

1. Adenubi, O.T. et al (2016) Plant Extracts to Control Ticks of Veterinary and Medical Importance: A Review. South African Journal of Botany. (105) 178-193. 
2. Arthur, D.R. (1962). In: Ticks and Disease. Oxford pergamon press: pp 445.

3. Askira, Z.K and Sodipo, O.A. (2002): $22^{\text {nd }}$ annual Conference of the Nigeria society of Biochemistry and Molecular biology. Book of Abstracts pp 36.

4. Awogbade, M.O. (1979) Fulani Pastoralism and the Problems of the Nigerian Vetrinary Service. Afr Aff 1979, 78: 493-506.

5. Bayer, W and J.A. Maina (1984) Seasonal Pattern of Tick load in Bunaji Cattle in the Sub-humid zone of Nigeria. Vet Parasitol. 15:301-307.

6. Burkill, H.M. (1994). The useful plants of West Tropical Africa (Families E-J). Kew: Royal Botanical Gardens; 1994, p. 90-94.

7. Damter, S.A (2000): Studies on the Acaricidal Properties of Nicotiana Tobaccum on the Ectoparasites (Ticks of catties). Unpublished HND Project. Forestry Department, Federal College of Forestry, Jos Plateau State Nigeria.

8. Dipeolu, O.O. (1975) The Incidence of Ticks of Boophilus species on Cattle, Sheep and Goats in Nigeria. Tropical Anim Health Prod, 7: 35-39.

9. Encyclopaedia Britanica (2005).

10. Ghosh, M.S., Wahl, M., Kumar, M. and A. Ganguli (2007) Prevalence of Enterotoxigenic Staphylococcus aureus and Shigella spp. in some raw street vended Indian foods. Int J. Environ Health Res., 17: 151-156.

11. Graf, J.F. et al (2004) Tick Control: An Industry point of View Parasitology. 2004; 129. Suppl: S427-42.

12. Gionetto, F. and Chávez, E. C. (2000). Desarrollo actual de las investigaciones alelopaticas de la producción de insecticidas botánicos en Michoacán (México). pp. 123134. In: Memórias do Simposio Nacional Sobre Substancias Vegetales y Minerales em el Combate de Plagas, Abstracts, Acapulco, Mexico.

13. Lorusso, V., Picozzi, K., de Bronsvoort, B.M., Majekodunmi, A., Dongkum, C., Balak, G., Igweh, A and Welburn, S.C (2013) Ixodid ticks of traditionally managed cattle in central Nigeria: where Rhipicephalus (Boophilus) microplus does not dare (yet?). Parasit Vectors. Jun 7; 6: 171. https://doi.org/10.1186/1756-3305-6-171.

14. McGraw-Hill Encyclopaedia (1977): Vol. 5, page 445-451 Mgbojikwe, L.O. and Okoye, Z.S.C (1998): The Toxic Effects of the Aqueous Stem Bark Extract of Adenium Obesum to the Various Life Cycles of the Cattle Tick. Accepted for publication in the journal of the Nigerian society of Entomology.

15. Okujagu TF, Etatuvie SO, Eze I, Jimoh B, Nweke C, Mbaoji C (2006) editors. Medicinal Plants of Nigeria; South-west Nigeria. 1st Edited. Lagos: University of Lagos, p. 1-20.

16. Pullan, N.B. (1987) Productivity of white Fulani Cattle in the Jos Plateau, Nigeria: Diseases and Management factors. Trop Anim Health. 12:77-84.

17. Russel P.H and Alexander, D.J. (1956). Antigenic variation of Newcastle disease virus strains detected by monoclonal Antibodies. Archives of Virology 75: 243-253

18. Sangwan, A.K., Chabra, MB., Singh, S. (1993): Acaricide Resistance Status of Common Livestock Ticks in Haryana. Indian Veterinary Journal, 70(1): 20-24.

19. Sanis, J., Reghu, R., Sunil, A., Ajith Kumar, K.G., Suresh, N., Amithamol, K., Amitabh, B., Ajay K S Rawat and Srikanta Ghosh (2011) Jatropha curcas (Linn) leaf extract- a possible alternative for population control of Rhipicephalus (Boophilus) annulatus. Asian Journal of Tropical Disease (2011) 225-229.

20. Sofowora, A. (1979): African Medicinal Plants. University of Ife Press, Ife. Pp 97-112 Solomon,.K.R.' (1983); Acaricidalresistance in Ticks. Advances in Veterinary Science and Comparative Medicine 27:273-. 296.

21. Trease, G.E. and Evans, W.C (1989), In: A Textbook of Pharmacognosy, $13^{\mathrm{m}}$ Edu. Bailliere Tindall Ltd., London. pp 56.

22. Wall, M.E., Eddy, C.R., McClenna, Ml and Klump, ME.' (1952): Detection and Estimation of Steroid Sapogenins in Plant Tissue, Analytical chemistry 24; 1337-1315.

23. Wall, M.E. et al (1954): Steroidal Sapoyenins Xiii. Supplementary table of data for steroidal vii. Agricultural research services circulation-vol. 363 pp 17.

24. Willis, T.E. (1967) Text book of Pharmacognosy. London: J and A Churchill Ltd; 1967, p. 513-524. 